Primljen / Received: 14.8.2013.

Ispravljen / Corrected: 2.11.2013.

Prihvaćen / Accepted: 15.11.2013.

Dostupno online / Available online: 10.1.2014.

\section{Park-Ang damage index for adjacent steel frames under pounding}

\section{Authors:}

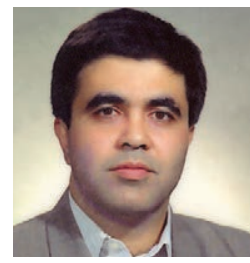

Assoc.Prof. Javad Vaseghi Amiri, PhD. CE Noshirvani University of Technology Department of Civil Engineering Babol, Iran vaseghi@nit.ac.ir

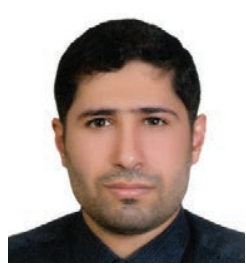

Sayyed Ghasem Jalali, PhD. Candidate Noshirvani University of Technology Department of Civil Engineering Babol, Iran sg.jalali@stu.nit.ac.ir
Preliminary note

\author{
Javad Vaseghi Amiri, Sayyed Ghasem Jalali
}

\section{Park-Ang damage index for adjacent steel frames under pounding}

The pounding of two adjacent 3-bay and 5-bay 5-storey frames is studied in this paper. These frames are analysed under eight different ground motions in two leftto-right and right-to-left directions for 17 separations between them. Park- Ang damage indices of adjacent frames are studied. The results show that the use of elastic impact elements is generally conservative. The direction of ground motion influences the level of damage of colliding structures. The separation equalling to $1 \%$ of storey height can eliminate or strongly decrease pounding force.

Key words:

Structural pounding, Park-Ang damage index, absorbed energy, impact elements, nonlinear dynamic analysis

Javad Vaseghi Amiri, Sayyed Ghasem Jalali

Prethodno priopćenje

\section{Park-Angov indeks oštećenja sudara susjednih čeličnih okvirnih konstrukcija}

$U$ radu se analizira sudar dviju susjednih petokatnih okvirnih konstrukcija od kojih jedna ima tri a druga pet polja. Konstrukcije su analizirane za osam raznih pomaka tla u dva smjera (od lijeve strane prema desnoj i obratno) za 17 razmaka izmedu građevina. Analiziraju se indeksi oštećenja Park-Ang za susjedne okvire. Rezultati pokazuju da se primjena udarnih elemenata može uglavnom smatrati konzervativnom. Smjer pomaka tla utječe na stupanj oštećenja konstrukcija u sudaru. Razmakom od $1 \%$ od visine kata eliminira se ili bitno umanjuje sila sudara.

Ključne riječi:

sudar konstrukcija, Park-Angov indeks oštećenja, apsorbirana energija, sudarni elementi, nelinearna dinamička analiza

Vorherige Mitteilung

Javad Vaseghi Amiri, Sayyed Ghasem Jalali

Park-Ang Schadensindex für miteinander anstoßende Stahlrahmenkonstruktionen

In dieser Arbeit wird das Anstoßen zwei anliegender fünfstöckiger Rahmenkonstruktionen mit drei und fünf Spannweiten untersucht. Die Rahmen sind unter acht Erdbebenaufzeichnungen in zwei Richtungen, links-rechts und rechts-links, für 17 Trennungsabstände. Park-Ang Schadensindexe sind ermittelt worden. Die Resultate zeigen, dass die Anwendung von Prallelementen allgemein konservativ ist. Die Richtung der Bodenbewegung beeinflusst das Schadensausmaß der anstoßenden Konstruktionen. Trennungsabstände, die 1\% der Stockwerkshöhe betragen, können Aufprallkräfte eliminieren oder stark mindern.

Anstoßen von Konstruktionen, Park-Ang Schadensindex, absorbierte Energie, Aufprallelemente, nichtlineare dynamische Analysen 


\section{Introduction}

In severe earthquakes that have occurred over the past decades, the pounding has induced considerable damage to, or caused collapse of, adjacent structures without sufficient separation, which have different characteristics and can vibrate out-of-phase. During the earthquake that struck Mexico City in 1985, the pounding was observed in $40 \%$ of 330 collapsed or severely damaged structures; in $15 \%$ of the collapsed structures, it was the major cause of collapse [1]. Kasai and Maison report that, in the Loma Prieta earthquake, 200 pounding occurrences, involving more than 500 buildings, were observed at sites that are over $90 \mathrm{~km}$ away from the epicentre [2]. A review of the evidence and types of structural pounding, which has occurred in previous earthquakes, is presented by Anagnostopoulos [3, 4].

The pounding is a complex phenomenon that is associated with uncertainties in modelling. There are two basic modelling approaches for the analysis of pounding; stereomechanical approach and contact element approach [5]. The stereomechanical approach uses the momentum principle and coefficient of restitution to determine velocities of bodies that collide after impact. Due to its simplicity and use of finite elements, the contact element approach is commonly used to model pounding. In this study, it is preferred that contact elements be called impact elements during dynamic loading. These elements can have linear or nonlinear elastic, and viscoelastic behaviour.

The linear impact element is the simplest contact element used for impact modelling. This element has been used to model pounding by Stoykovich [6], Maison and Kasai [7, 8] and Karayannis and Favvata [9]. However, this element cannot take into account the loss of energy during impact.

The linear viscoelastic model can consider energy loss during impact. Shatoff et al. used this element to study performance of gas-cooled reactor members [10]. Anagnostopoulos [11] and Anagnostopoulos and Karamaneas [12] studied structural pounding by this element.

The hertz contact model was introduced by Hertz, and Goldsmith showed that this model could be in good agreement with experimental data [5].

The Hertzdamp contact model, in which a nonlinear elastic spring is used in conjunction with a nonlinear damper is proposed by Lankarani and Nikravesh [13]. Muthukumar and Desroches applied this element to study pounding of adjacent SDOFs and revealed that the effect of pounding is negligible when the ratio of two adjacent SDOFs periods is bigger than $0.7[14,15]$.

Jankowski proposed a nonlinear viscoelastic impact model and obtained good agreement using this element rather than the elastic or linear elements by comparing numerical modelling results with experimental impact data [16]. He applied this pounding model to study impact of two adjacent three-storey structures and found that the pounding force was significant for designing the lighter structure [17].

Mahmood et al. compared results of nonlinear viscoelastic and hertzdamp impact models with experimental results and indicated that these models lead to minor displacement and velocity errors, respectively [18]. Vaseghi and Jalali compared numerical results of hertzdamp, linear and nonlinear elastic and viscoelastic impact modelling, with experimental data, and found that good agreement of velocity response was achieved by applying elastic models. The Hertzdamp model was the best one to predict the pounding force. Significant differences were not observed in displacement response using different impact models [19].

Damage to structure can be a function of displacement, ductility, absorbed energy, stiffness, etc. The damage index can reveal the condition of structures. In most damage indices, 0.0 and 1.0 values express no damage and collapse, respectively. Veletsos and Newmark used ductility as a damage index [20]. Lybas and Sozen proposed damage index as the ratio of initial stiffness to secant stiffness corresponding to maximum deformation [21]. Park and Ang proposed a damage index that combined the ratio of maximum to ultimate deformation and hysteretic energy [22]. Roufaiel and Meyer defined a damage index using flexural flexibility [23]. The damage index based on quadratic dissipated energy was introduced by McCabe and Hall [24]. Also, an energy-based damage index was proposed by Fajfar for elastic-perfectly-plastic systems [25].

The pounding of two adjacent 3-bay 5-storey and 5-bay 5 -storey frames is studied in this paper. Different impact elements are applied between adjacent frames to study the effect of collision type. These elements are programmed by Visual $\mathrm{C}+$ and added to the OpenSees library. Nonlinear dynamic time history analyses are carried out for eight ground motion records in different gaps between the frames. Finally, the Park-Ang damage index of the frames is assessed taking into account different impact elements.

\section{Impact elements and damage index}

For example, two adjacent SDOFs, and the impact element between them under seismic excitation $\left(\ddot{U}_{q}\right)$, are shown in Figure 1. If the relative displacement of two ends $\left(u_{1}-u_{2}\right)$ of the impact element is larger than its gap $\left(g_{p}\right)$, then the pounding can take place. Responses of adjacent SDOFs affect each other and depend on their properties such as masses ( $m_{1}$ and $\left.m_{2}\right)$, values of stiffness $\left(k_{1}\right.$ and $\left.k_{2}\right)$ and damping (equivalent: $C_{1}$ and $C_{2}$ ). Impact element characteristics can be related to SDOFs masses, densities ( $\rho_{1}$ and $\rho_{2}$ ) coefficients of restitution $\left(e_{1}\right.$ and $\left.e_{2}\right)$, yield and ultimate impact material stresses, 
shape of impact body, etc. These increase complexity of the pounding phenomenon. For simplicity, the impact elements that are studied here include linear or nonlinear elastic and viscoelastic collisions.

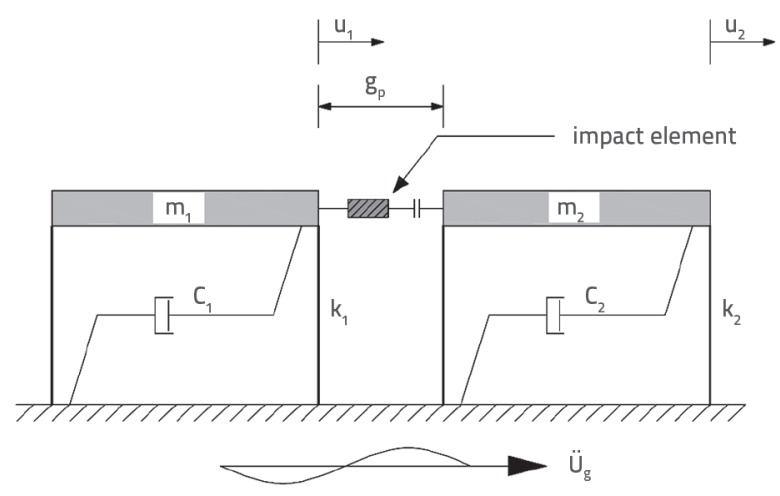

Figure 1. Adjacent SDOFs with the impact element between them

\subsection{Linear elastic impact element}

This contact model is the simplest impact element and applies a linear elastic spring with a gap. Its pounding force is expressed as:

$F_{1}=0 \quad$ if $\quad \delta(t) \leq 0$

$F_{1}=k_{l} \delta(t) \quad$ if $\quad \delta(t)>0$

$\delta=u_{1}-u_{2}-g_{p}$

where $F_{1}$ is the pounding force, $u_{1}$ and $u_{2}$ denote displacements of adjacent bodies. $g_{p}$ is the gap in impact element. If the gap is closed, the impact element can be active and get force. $k_{l}$ is the impact element stiffness and equals in-plane stiffness of stiffer structure, or 20 times of storey stiffness [11], or an unlimited value $[7,8]$.

\subsection{Linear viscoelastic impact element}

This impact element constitutes a linear elastic impact element which is in conjunction with a linear viscous damper. Therefore, this element can include the effect of energy that is dissipated during the impact. Its contact force is described as:

$$
\begin{aligned}
& F_{1}=0 \quad \text { if } \quad \delta(t) \leq 0 \\
& F_{1}=k_{l} \delta(t)+C_{k} \dot{\delta}(t) \quad \text { if } \quad \delta(t)>0 \\
& C_{k}=2 \xi \sqrt{k_{l}\left(\frac{m_{1} m_{2}}{m_{1}+m_{2}}\right)} \\
& \xi=-\frac{\ln e}{\sqrt{\pi^{2}+(\ln e)^{2}}} \\
& \dot{\delta}=\dot{u}_{1}-\dot{u}_{2}
\end{aligned}
$$

where $C_{k}$ expresses equivalent damper of impact element. $m_{1}, m_{2}, \dot{u}_{1}$ and $\dot{u}_{2}$ denote masses and velocity of colliding bodies, respectively, and $e$ is coefficient of restitution [11]. Goldsmith proposed the value $=0,65$ for collision of concrete bodies [5].

\subsection{Nonlinear elastic impact element}

This element acts like a nonlinear elastic spring. Impact force of this element is obtained from

$\begin{array}{lll}F_{1}=0 & \text { if } & \delta(t) \leq 0 \\ F_{1}=k_{h} \delta(t)^{3 / 2} & \text { if } & \delta(t)>0\end{array}$

where is $k_{h}$ the nonlinear contact stiffness:

$k_{h}=\frac{4}{3 \pi\left(h_{1}+h_{2}\right)}\left[\frac{R_{1} \cdot R_{2}}{R_{1}+R_{2}}\right]$

$R_{i}=\sqrt[3]{\frac{3 m_{i}}{4 \pi \rho_{i}}}$

$h_{i}=\frac{1-\gamma_{i}}{\pi \cdot E_{i}}$

where are $\rho_{i} E_{i}, \gamma_{i}$ and $R_{i}$ express the density, modulus of elasticity, Poison's ratio, and equivalent radius of colliding bodies, respectively [5].

\subsection{Hertzdamp impact element}

This colliding model considers a nonlinear elastic spring in connection with a nonlinear viscous damper. Its pounding force can be calculated by the following formula

$\begin{array}{lll}F_{1}=0 & \text { if } & \delta(t) \leq 0 \\ \mathrm{~F}_{1}=\mathrm{k}_{\mathrm{h}} \delta^{\frac{3}{2}}\left[1+\frac{3\left(1-\mathrm{e}^{2}\right)}{4\left(v_{1}-v_{2}\right)} \dot{\delta}(\mathrm{t})\right] & \text { if } & \delta(t)>0\end{array}$

where are $v_{1} \mathrm{i} v_{2}$ are velocities of colliding bodies before pounding [13].

\subsection{Nonlinear viscoelastic impact element}

This element jointly considers the nonlinear elastic and viscous behaviour, and eliminates damping force of negative velocity. The force of this type of collision is calculated as :

$\begin{array}{lll}F(t)=\bar{\beta} \delta^{\frac{3}{2}}(t)+\bar{c}(t) \delta(t) & \text { if } & \delta(t)>0, \delta>0 \\ F(t)=\bar{\beta} \delta^{\frac{3}{2}}(t) & \text { if } & \delta(t)>0, \dot{\delta} \leq 0 \\ F(t)=0 & \text { if } & \delta(t) \leq 0\end{array}$

$\bar{c}(t)=2 \bar{\xi} \sqrt{\bar{\beta} \sqrt{\delta(t)} \frac{m_{1} m_{2}}{m_{1}+m_{2}}}$ 


$$
\bar{\xi}=\frac{9 \sqrt{5}}{2} \frac{1-e^{2}}{e(e(9 \pi-16)+16)}
$$

where are $\bar{\beta}$ and $\bar{C}$ denote stiffness and equivalent damper of the impact element, respectively, and $\bar{\beta}$ is expressed based on experimental results [16]

Based on experimental results, Jankowski proposed the coefficient of restitution as a function of relative pre-impact velocity, which could be applied in numerical modelling. For steel to steel contact, $e$ is formulated as:

$$
e=-0,0039 v^{3}+0,00440 v^{2}-0,1867 v+0,7299
$$

where $v$ is the relative velocity prior to impact [26].

The OpenSees software [27] is used for analysis in this paper. Programs of different impact elements are developed in Visual C+t and added to the OpenSees library. Eq. (15) is used in programming to compute the coefficient of restitution. Validations by numerical and experimental data were performed by Vaseghi and Jalali [19].

\subsection{Damage index}

Damage indices have been extensively used to express condition of the structure in seismic events. Park and Ang proposed a damage index as a relation between the ratio of maximum to ultimate deformation and hysteretic energy.

$D I_{P A}=\frac{\delta_{m}}{\delta_{u}}+\frac{\beta}{\delta_{u} p_{y}} \int d E_{h}$

where $\delta_{m^{\prime}} \delta_{u}$ i $p_{y}$ are maximum, ultimate deformations under monotonic loading and yield strength, respectively. In this study, the rotation $(\theta)$ and moment $(M)$ are considered as the deformation and strength, respectively. $\int d E_{h}$ denotes the hysteretic energy absorbed by the element during the earthquake. $\beta$ is the non-negative strength deteriorating constant and equals 0.025 for the $\mathrm{H}$-shaped steel member [22]. The ultimate rotation under monotonic loading $\left(\theta_{u}\right)$ can be related to yield rotation $\left(\theta_{y}\right)$ by ultimate ductility $\left(\mu_{u}\right)$ :

$\theta_{u}=\mu_{u} \cdot \theta_{y}$

According to FEMA356 (Chapter (5), Table (5-6)), the ultimate to yield rotation of ductile flexural members $\left(\mu_{u}\right)$ is considered equal to 11 [28].

The damage index of a structure can be generated by correlation of members' damage indices and their absorbed energy. These correlation formulae are presented as:

$$
\begin{aligned}
& D I_{\text {kat }}=\sum(\lambda)_{\text {element }}(D I)_{\text {element }} \\
& \left(\lambda_{i}\right)_{\text {element }}=\left(\frac{E_{i}}{\sum E_{i}}\right)_{\text {element }} \\
& D I_{\text {ukupno }}=\sum(\lambda)_{\text {kat }}(D I)_{\text {kat }} \\
& \left(\lambda_{\mathrm{i}}\right)_{\text {kat }}=\left(\frac{E_{i}}{\sum E_{i}}\right)_{\text {kat }}
\end{aligned}
$$

where $D I_{P A}$ and $E_{i}$ are the Park-Ang damage index and the absorbed energy of $i^{\text {th }}$ member or storey. $E_{i}$ is determined for each member and storey. $\lambda_{i}$ is the ratio of the absorbed energy of the $\mathrm{i}^{\text {th }}$ member or storey to total member of storey or structure, respectively [29]. $D I_{P A}=1,0$ shows total collapse. It can be noticed that, $\delta_{m}$ is commonly non-zero. Therefore even a member has no damage, $D I_{P A}$ has a non-zero value. But if a member stands on an elastic state, its absorbed energy is zero and according to Eqs. (18) and (19) it does not affect the storey or structure damage index.

\section{Frame modelling and analysis}

Effects of different impact elements are determined by nonlinear dynamic analyses of two adjacent 3- and 5-bay 5 -storey steel frames. The bay length and storey height are 5 and $3.2 \mathrm{~m}$, respectively. Dead and live loads of the left frame (3-bay frame) are 29418 and $9806 \mathrm{~N} / \mathrm{m}$, and loads for the right frame (5-bay frame) are twice as great as those for the left frame; this is related to the study of effect of the pounding force on the lighter frame. The mass participation ratio of live load is equal to $20 \%$. Average storey masses of 3- and 5-bay frames are calculated as 50100 and $165000 \mathrm{~kg}$, respectively. The site class C has been adopted according to USGS [30]. Iranian Code of Buildings Design against Earthquake (Standard 2800) [31], and Iranian Steel Frame Manual (similar to AISC-ASD89 [32]), are used for frame design. According to Standard 2800, the frames selected for this study are of medium importance.

Main periods of 3- and 5-bay frames are 1.080 and $0.912 \mathrm{~s}$, respectively. According to Standard 2800, if buildings have less than 8 storeys and are of low or medium importance, each building storey must be separated by $0.5 \%$ of its height from boundary of the adjacent territory. In other words, these two frames must be separated by $1 \%$ of their heights from each other. Accordingly, these two frames must be separated $0.16 \mathrm{~m}$ away from each other. According to UBC97, adjacent structures should be separated by at least $\Delta_{\mathrm{MT}}$ :

$\Delta_{M T}=\sqrt{\left(\Delta_{M 1}\right)^{2}+\left(\Delta_{M 2}\right)^{2}}$

where $\Delta_{\mathrm{M} 1}$ i $\Delta_{\mathrm{M} 2}$ are maximum non-elastic displacements from adjacent structures and are calculated by

$\Delta_{\mathrm{M}}=0,7 \mathrm{R} \Delta_{\mathrm{S}}$ 
Table 1. Ground motions selected for the analysis

\begin{tabular}{|c|c|c|c|c|c|c|}
\hline Name & Date & Station & Component & $\begin{array}{c}\text { PGA } \\
{[\mathrm{g}]}\end{array}$ & $\begin{array}{c}\text { Distance } \\
{[\mathrm{km}]}\end{array}$ & Magnitude \\
\hline Loma Prieta & 18.10.1989. & 47381 Gilroy Array & G03090 & 0,37 & 14,4 & Ms $(7,1)$ \\
\hline Superstitn Hills & 24.11 .1987$. & 01335 El Centro Imp, Co, Cent & B-ICCOOO & 0,36 & 13,9 & Ms $(6,6)$ \\
\hline Northridge & 17.1.1994. & 90091 LA - Saturn St & STN110 & 0,44 & 30,0 & Ms $(6,7)$ \\
\hline Whittier Narrows & 1.10 .1987$. & 90077 Santa Fe Springs - E Joslin & A-EJSO48 & 0,43 & 10,8 & Ms $(5,7)$ \\
\hline Chi-Chi & 20.9.1999. & TCU074 & TCU074-W & 0,59 & 13,67 & Ms $(7,6)$ \\
\hline Cape Mendocino & 25.4.1992. & 89156 Petrolia & PETOOO & 0,59 & 9,5 & Ms $(7,1)$ \\
\hline Chi-Chi & 20.9.1999. & TCU079 & TCU079-W & 0,74 & 10,04 & Ms $(7,6)$ \\
\hline Duzce & 12.11.1999. & Bolu & BOLOOO & 0,73 & 17,6 & Ms $(7,3)$ \\
\hline
\end{tabular}

Table 2. Stiffness of impact elements between different storeys of adjacent frames

\begin{tabular}{|c|c|c|c|c|c|}
\hline \multirow{2}{*}{ Element stiffness } & \multicolumn{4}{|c|}{ Stiffness of impact elements } \\
\cline { 2 - 5 } & Storey 1 & Storey 2 & \multicolumn{2}{|c|}{ Storey $\mathbf{3}$} & \multicolumn{1}{|c|}{ Storey $\mathbf{4}$} \\
\hline Linear stiffness [N/m] & $6,37 \times 10^{9}$ & $1,6 \times 10^{9}$ & $8,01 \times 10^{8}$ & $4,71 \times 10^{8}$ & $2,65 \times 10^{8}$ \\
\hline Nonlinear stiffness [N/m $\left.{ }^{1,5}\right]$ & $131,0 \times 10^{9}$ & $131,0 \times 10^{9}$ & $131,0 \times 10^{9}$ & $131,0 \times 10^{9}$ & $131,0 \times 10^{9}$ \\
\hline
\end{tabular}

where $R$ is the numerical coefficient representative of the inherent overstrength and global ductility capacity of lateralforce-resisting systems [33]. Eq. (20) is considered in this study; however, it is used to calculate separation of adjacent buildings of similar properties. According to Standard 2800, $R$ value amounts to $7 . \Delta_{\mathrm{S}}$ is the design level response displacement under seismic design loads; it amounts to 0.052 and $0.043 \mathrm{~m}$ for the left and right frames, respectively. According to the UBC regulation, $\Delta_{\mathrm{MT}}$ amounts to $0.331 \mathrm{~m}$.

Eight ground motions from the PEER strong motion database [34] for USGS soil class C were selected to analyze the adjacent frames. Their characteristics are shown in Table 1. To study direction of excitation, these records have been separately induced in two directions (left-to-right and right-to-left). It is assumed that these selected ground motions are left-to-right and can turn right-to-left through multiplication of their data by -1. The analyses were carried out using the OpenSees [27] with Visual C++ programming. The Visual C++ was applied to program new pounding elements and their use in the OpenSees. The beam-column element with distributed plasticity was selected to model beams and columns. Each storey was considered to be a rigid diaphragm to remove axial forces in beams. The yielding stress, Poisson's ratio, modulus of elasticity, density and strain hardening of steel amounted to $240 \mathrm{MPa}, 0.3,200 \mathrm{GPa}, 7850$ $\mathrm{kg} / \mathrm{m}^{3}$ and $3 \%$, respectively. The dependence of velocity on the coefficient of restitution was calculated according to Eq. (15). The stiffness of linear elastic and viscoelastic elements between each storey was determined as being equal to 20 times the storey stiffness for the harder frame. The stiffness of nonlinear elements was obtained from Eqs. (8) to (10). Eqs (4) and (13) were used to calculate dampers of linear and nonlinear viscoelastic elements, respectively. Table 2 presents stiffness values for different impact elements. 1360 nonlinear time history analyses were performed to study structural pounding. The analysis intervals amounted to $0.001 \mathrm{~s}$; however, in some cases involving convergence, this interval was reduced to $0.00025 \mathrm{~s}$.

\section{Results}

The pounding of two frames, with an impact element between them, is studied at 17 distances from 0.00 to $0.16 \mathrm{~m}$, with $0.01 \mathrm{~m}$ increments. In some cases, the pounding force at separation equaling to $0.16 \mathrm{~m}$ is not zero. Therefore, some extra analyses have been conducted to determine adequate separations in which the pounding force is zero. Then some separations greater than $0.16 \mathrm{~m}$ are presented. The yield and maximum rotations of members are determined at every distance using their hysteretic curves, and damage indices of members are calculated according to Eq. (16). After that, absorbed energies of members are calculated, and the damage index of each storey is obtained from damage indices and absorbed energies of its components using Eq. (18). According to Eq. (19), the frame damage index is similarly calculated from damage indices and absorbed energies of storeys. The damage index equaling to 1.0 means the failure of storey or frame. But in some cases, if damage indices greater than 1.0 are deleted, the effect of using different impact elements can not be studied. Therefore, damage indices greater than 1.0 are presented in tables and graphs only for comparing the effects of using different impact elements.

The results show that the application of various pounding elements has a minor effect on damage index of the heavy 5-bay frame, compared to the light 3-bay frame. As far as extensive results are concerned, a summary of damage indices for the 5-bay frame is presented. The results for the 3-bay frame 
Table 3. Maximum and minimum damage index (DI) of 5-bay frame for L-R (left-to-right) and R-L (right-to-left), directions of excitation according to the hertzdamp model

\begin{tabular}{|c|c|c|c|c|c|c|c|}
\hline Ground motion & Direction & $\begin{array}{c}\text { Maximum DI } \\
\text { with pounding }\end{array}$ & $\begin{array}{c}\text { Gap of } \\
\text { Maximum DI }\end{array}$ & $\begin{array}{c}\text { Minimum DI } \\
\text { with pounding }\end{array}$ & $\begin{array}{c}\text { Gap of } \\
\text { Minimum DI }\end{array}$ & $\begin{array}{l}\text { Dl without } \\
\text { pounding }\end{array}$ & $\begin{array}{l}\text { Gap when pounding } \\
\text { force is zero }(0.00)\end{array}$ \\
\hline \multirow{2}{*}{ Loma Prieta } & L-R & 0,2794 & 0,01 & 0,2391 & 0,07 & 0,2366 & 0,13 \\
\hline & $\mathrm{R}-\mathrm{L}$ & 0,2392 & 0,07 & 0,2177 & 0,03 & 0,2366 & 0,13 \\
\hline \multirow{2}{*}{ Superstitn Hills } & L-R & 0,3189 & 0,11 & 0,2712 & 0,01 & 0,3189 & 0,11 \\
\hline & $\mathrm{R}-\mathrm{L}$ & 0,3189 & 0,09 & 0,2850 & 0,00 & 0,3189 & 0,09 \\
\hline \multirow{2}{*}{ Northridge } & $L-R$ & 0,9272 & 0,03 & 0,9259 & 0,02 & 0,9263 & 0,04 \\
\hline & $\mathrm{R}-\mathrm{L}$ & 0,9319 & 0,12 & 0,8729 & 0,02 & 0,9263 & 0,19 \\
\hline \multirow{2}{*}{$\begin{array}{l}\text { Whittier } \\
\text { Narrows }\end{array}$} & L-R & 0,2838 & 0,00 & 0,2736 & 0,01 & 0,2800 & 0,10 \\
\hline & $\mathrm{R}-\mathrm{L}$ & 0,3022 & 0,00 & 0,2796 & 0,04 & 0,2800 & 0,11 \\
\hline \multirow{2}{*}{$\begin{array}{l}\text { Chi-Chi } \\
\text { (TCU074) }\end{array}$} & L-R & 1,1344 & 0,00 & 1,0200 & 0,16 & 1,0314 & 0,17 \\
\hline & $R-L$ & 1,2149 & 0,03 & 1,0015 & 0,14 & 1,0314 & 0,19 \\
\hline \multirow{2}{*}{$\begin{array}{c}\text { Cape } \\
\text { Mendocino }\end{array}$} & $L-R$ & 0,7248 & 0,03 & 0,6967 & 0,01 & 0,7157 & 0,13 \\
\hline & $\mathrm{R}-\mathrm{L}$ & 0,7157 & 0,16 & 0,6766 & 0,01 & 0,7157 & 0,17 \\
\hline \multirow{2}{*}{ Duzce } & $L-R$ & 0,7416 & 0,00 & 0,6721 & 0,06 & 0,6874 & 0,16 \\
\hline & $\mathrm{R}-\mathrm{L}$ & 0,7015 & 0,01 & 0,6669 & 0,03 & 0,6874 & 0,10 \\
\hline \multirow{2}{*}{$\begin{array}{l}\text { Chi-Chi } \\
\text { (TCU079) }\end{array}$} & $L-R$ & 1,0192 & 0,16 & 0,9567 & 0,01 & 1,0198 & 0,18 \\
\hline & $R-L$ & 1,0188 & 0,16 & 0,9305 & 0,00 & 1,0198 & 0,18 \\
\hline
\end{tabular}

Table 4. Maximum and minimum DI of 3-bay frame for L-R and R-L directions of excitation considering hertzdamp model

\begin{tabular}{|c|c|c|c|c|c|c|c|}
\hline Ground motion & Direction & $\begin{array}{c}\text { Maximum DI } \\
\text { with pounding }\end{array}$ & $\begin{array}{c}\text { Gap of } \\
\text { Maximum DI }\end{array}$ & $\begin{array}{c}\text { Minimum DI } \\
\text { with pounding }\end{array}$ & $\begin{array}{c}\text { Gap of } \\
\text { Minimum DI }\end{array}$ & $\begin{array}{l}\text { DI without } \\
\text { pounding }\end{array}$ & $\begin{array}{l}\text { Gap when pounding } \\
\text { force is zero }(0.00)\end{array}$ \\
\hline \multirow{2}{*}{ Loma Prieta } & $L-R$ & 0,2498 & 0,07 & 0,1197 & 0,00 & 0,2457 & 0,13 \\
\hline & $R-L$ & 0,2659 & 0,09 & 0,1721 & 0,00 & 0,2457 & 0,13 \\
\hline \multirow{2}{*}{ Superstitn Hills } & $L-R$ & 0,2411 & 0,08 & 0,1403 & 0,00 & 0,2411 & 0,11 \\
\hline & $R-L$ & 0,2411 & 0,09 & 0,1509 & 0,00 & 0,2411 & 0,09 \\
\hline \multirow{2}{*}{ Northridge } & $L-R$ & 0,6975 & 0,00 & 0,6528 & 0,02 & 0,6585 & 0,04 \\
\hline & $R-L$ & 0,6621 & 0,02 & 0,6032 & 0,03 & 0,6585 & 0,19 \\
\hline \multirow{2}{*}{$\begin{array}{l}\text { Whittier } \\
\text { Narrows }\end{array}$} & L-R & 0,2369 & 0,01 & 0,2042 & 0,03 & 0,2246 & 0,10 \\
\hline & $R-L$ & 0,2254 & 0,04 & 0,1631 & 0,00 & 0,2246 & 0,11 \\
\hline \multirow{2}{*}{$\begin{array}{l}\text { Chi-Chi } \\
\text { (TCU074) }\end{array}$} & L-R & 1,1330 & 0,05 & 0,9543 & 0,00 & 1,0429 & 0,17 \\
\hline & $R-L$ & 1,0819 & 0,12 & 0,8094 & 0,02 & 1,0429 & 0,19 \\
\hline \multirow{2}{*}{$\begin{array}{c}\text { Cape } \\
\text { Mendocino }\end{array}$} & $L-R$ & 0,5510 & 0,01 & 0,4508 & 0,12 & 0,4508 & 0,13 \\
\hline & $\mathrm{R}-\mathrm{L}$ & 0,5841 & 0,01 & 0,4445 & 0,11 & 0,4508 & 0,17 \\
\hline \multirow{2}{*}{ Duzce } & L-R & 0,5711 & 0,04 & 0,4676 & 0,00 & 0,5368 & 0,16 \\
\hline & $R-L$ & 0,6148 & 0,04 & 0,5368 & 0,10 & 0,5368 & 0,10 \\
\hline \multirow{2}{*}{$\begin{array}{l}\text { Chi-Chi } \\
\text { (TCU079) }\end{array}$} & $L-R$ & 0,8403 & 0,10 & 0,6418 & 0,03 & 0,8164 & 0,18 \\
\hline & $R-L$ & 0,8974 & 0,07 & 0,7896 & 0,01 & 0,8164 & 0,18 \\
\hline
\end{tabular}

are explained in greater detail. The Hertzdamp model applies damping and has fewer uncertainties; therefore, responses obtained by using different impact models are compared with the results of analysis using the hertzdamp model.

The results obtained by applying different impact elements to the total maximum and minimum damage indices of the 5-bay frame with and without pounding, considering the hertzdamp impact element, are given in Table 3. It can be seen that total damage indices for heavier frames with pounding, compared with damage indices without pounding, change by less than $5.5 \%$, with some exceptions (Loma Prieta, Chi-Chi (TCU074) and Superstition Hills). 
Table 5. Maximum absolute differences (\%) of DI of the 3-bay frame considering different impact elements, with comparison of hertzdamp model results

\begin{tabular}{|c|c|c|c|c|c|}
\hline Ground motion & Direction & $\begin{array}{l}\text { Maximum DI of linear } \\
\text { elastic impact model }\end{array}$ & $\begin{array}{l}\text { Maximum DI of linear } \\
\text { viscoelastic impact } \\
\text { model }\end{array}$ & $\begin{array}{l}\text { Maximum DI of } \\
\text { nonlinear elastic } \\
\text { impact model }\end{array}$ & $\begin{array}{l}\text { Maximum DI of nonlinear } \\
\text { viscoelastic impact model }\end{array}$ \\
\hline \multirow{2}{*}{ Loma Prieta } & $L-R$ & 6,55 & 6,81 & 3,09 & 2,02 \\
\hline & $\mathrm{R}-\mathrm{L}$ & 12,92 & 2,69 & 16,28 & 1,17 \\
\hline \multirow{2}{*}{ Superstitn Hills } & $L-R$ & 38,38 & 7,43 & 19,89 & 3,59 \\
\hline & $R-L$ & 16,35 & 6,44 & 9,83 & 2,70 \\
\hline \multirow{2}{*}{ Northridge } & $L-R$ & 1,26 & 0,76 & 1,02 & 0,54 \\
\hline & $\mathrm{R}-\mathrm{L}$ & 13,88 & 4,68 & 7,15 & 5,89 \\
\hline \multirow{2}{*}{$\begin{array}{l}\text { Whittier } \\
\text { Narrows }\end{array}$} & $L-R$ & 11,79 & 4,16 & 1,49 & 2,50 \\
\hline & $R-L$ & 13,44 & 6,83 & 2,05 & 1,92 \\
\hline \multirow{2}{*}{ Chi-Chi (TCU074) } & $L-R$ & 3,91 & 6,26 & 2,80 & 2,20 \\
\hline & $\mathrm{R}-\mathrm{L}$ & 6,40 & 3,66 & 5,55 & 2,51 \\
\hline \multirow{2}{*}{$\begin{array}{l}\text { Cape } \\
\text { Mendocino }\end{array}$} & L-R & 9,94 & 4,11 & 4,66 & 2,08 \\
\hline & $\mathrm{R}-\mathrm{L}$ & 4,95 & 4,22 & 5,01 & 2,99 \\
\hline \multirow{2}{*}{ Duzce } & $L-R$ & 10,06 & 2,64 & 4,99 & 0,62 \\
\hline & $\mathrm{R}-\mathrm{L}$ & 3,10 & 3,19 & 1,60 & 1,33 \\
\hline \multirow{2}{*}{ Chi-Chi (TCU079) } & $L-R$ & 7,42 & 5,44 & 5,47 & 3,41 \\
\hline & $\mathrm{R}-\mathrm{L}$ & 10,54 & 4,84 & 11,34 & 7,89 \\
\hline
\end{tabular}

Table 3 indicates that direction of the seismic excitation can affect damage index and separation to eliminate pounding force. Pounding can increase or decrease damage in different gaps. The results show that the application of impact elements has maximum ( $5.5 \%$ ) difference in the total damage index for all separations and ground motions. But, it is limited to $11.73 \%$ for the damage index of storeys.

Maximum Park-Ang damage indices for 3-bay frame storeys and the total frame are illustrated in Figures 2 to 9, where different impact elements, separations and ground motions are presented. Due to limited space, the paper shows ParkAngs damage indexes for certain cases: Loma Prieta (Figures 2 and 3), Superstitn Hills (Figures 4 and 5), North ridge (Figures 6 and 7) and Duzce (Figures 8 and 9).

Maximum damage indices for the 3-bay frame, based on the hertzdamp impact element, are presented in Table 4. Table 5 shows absolute maximum differences of damage indices considering different impact elements. According to Figures 2 to 9 and Table 5, a damage index can change based on the impact element selection, which is more obvious in lower PGAs in a limited number of gaps; however, in higher PGAs, it may have a smaller influence on damage indices but can occur on a greater number of gaps. The impact element selection obviously affects storeys' damage indices rather than the total damage index. It can be seen that application of the elastic and viscoelastic impact elements generally leads to greater and smaller damage. Therefore, the use of elastic impact elements is conservative; however, they cannot take into account the energy dissipated on impact, which may lead to a greater pounding force and non- realistic modelling. It is assumed that $\theta_{u}=11 \times \theta_{y^{\prime}}$ Therefore, just for yielding element and without any absorbed energy from the first part of Eq. (16), the damage index equals to at least:

$D_{P A}=\frac{\theta_{m}}{\theta_{u}}=\frac{\theta_{y}}{11 \times \theta_{y}}=\frac{1}{11}$.

It can be seen in Figures 5.a and 5.b that pounding forces of some impact elements lead to yielding members, but absorbed energies of members are low. Therefore, some elements experience damage index of at least 1/11. Because of low absorbed energies, this cannot significantly affect the total damage index, as can be seen in Figure 5.f.

Based on Figures 2 to 9 and Table 4, it is evident that the direction of seismic excitation significantly affects damage to the lighter frame. For example, in Figures 2.e and 3.e, damage to fifth storey is zero in left-to-right direction in zero gap; but, in right-to-left direction, in zero gap, the damage increases from the state without pounding. Similarly, it can be seen in Figures 6. , 7., 8. and 9. that the damage to some storeys in one direction of excitation is lower; but, in the opposite direction, it is more than the state without pounding. On the other hand, for instance, in Figure 8.f, the level of damage increases in some gaps but decreases in others in the same direction of excitation. Based on Figures 8. and 9, the damage to some storeys or to the entire frame in non-zero gaps is greater than the damage in zero gaps; it is remarkable that every separation is not safe between the neighbouring buildings. Therefore, it is recommended that the separation between adjacent structures be increased until the pounding effect becomes negligible. 

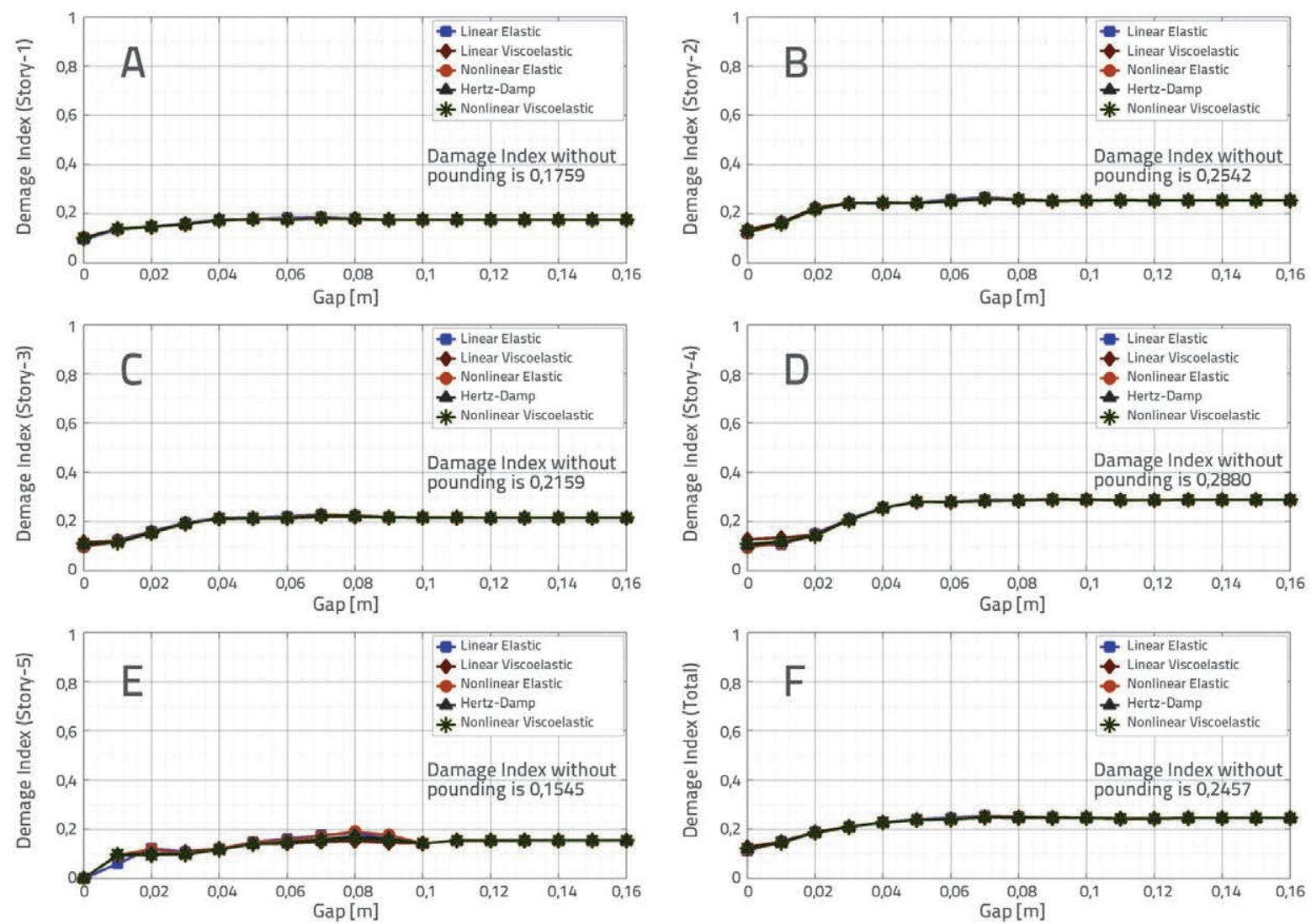

Figure 2. Park-Ang damage index in different separations for Loma Prieta, left-to-right, A-first, B-second, C-third, D-forth, E-fifth storey and F-total frame
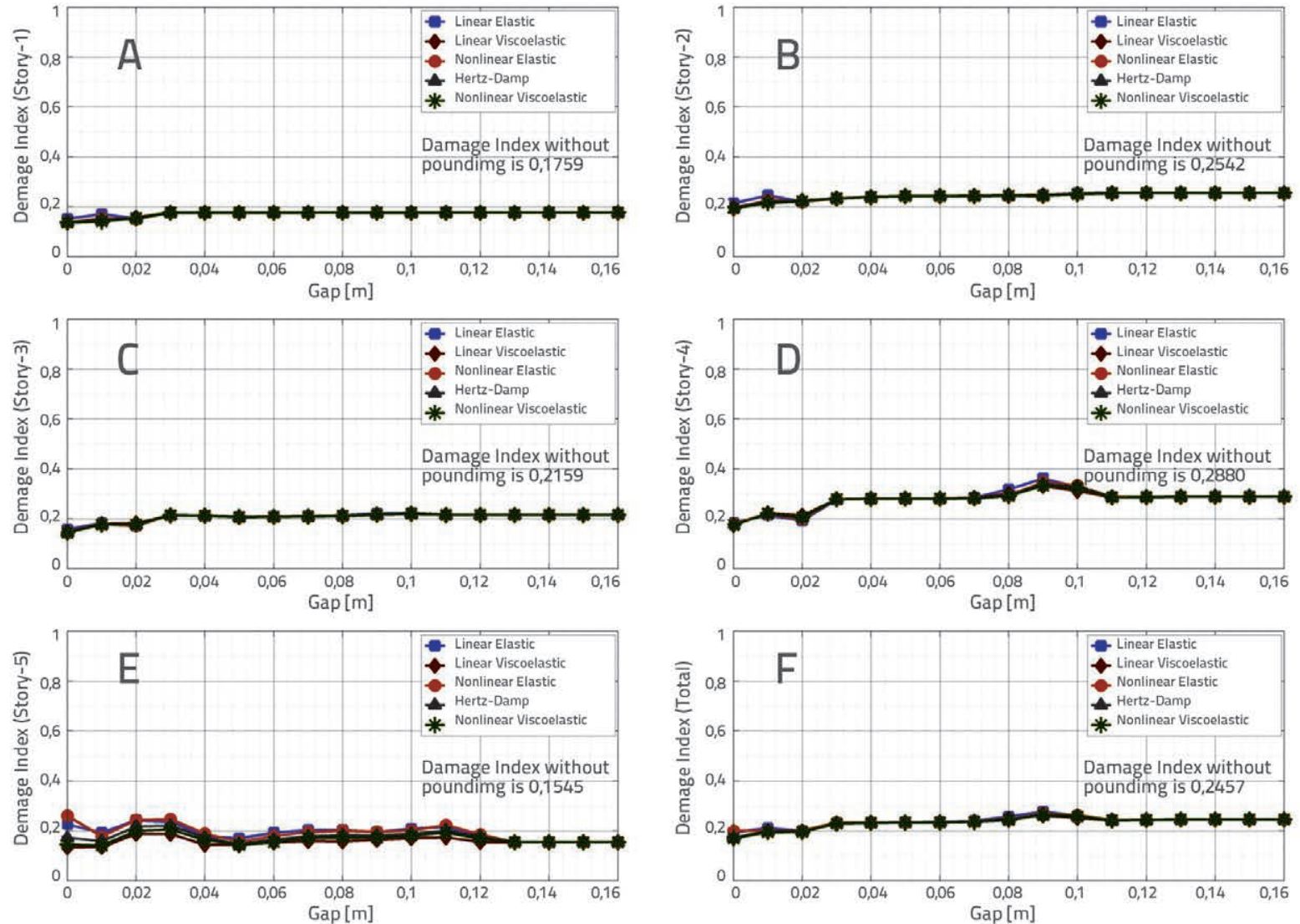

Figure 3. Park-Ang damage index in different separations for Loma Prieta, right-to-left, A-first, B-second, C-third, D-forth, E-fifth storey and F-total frame 

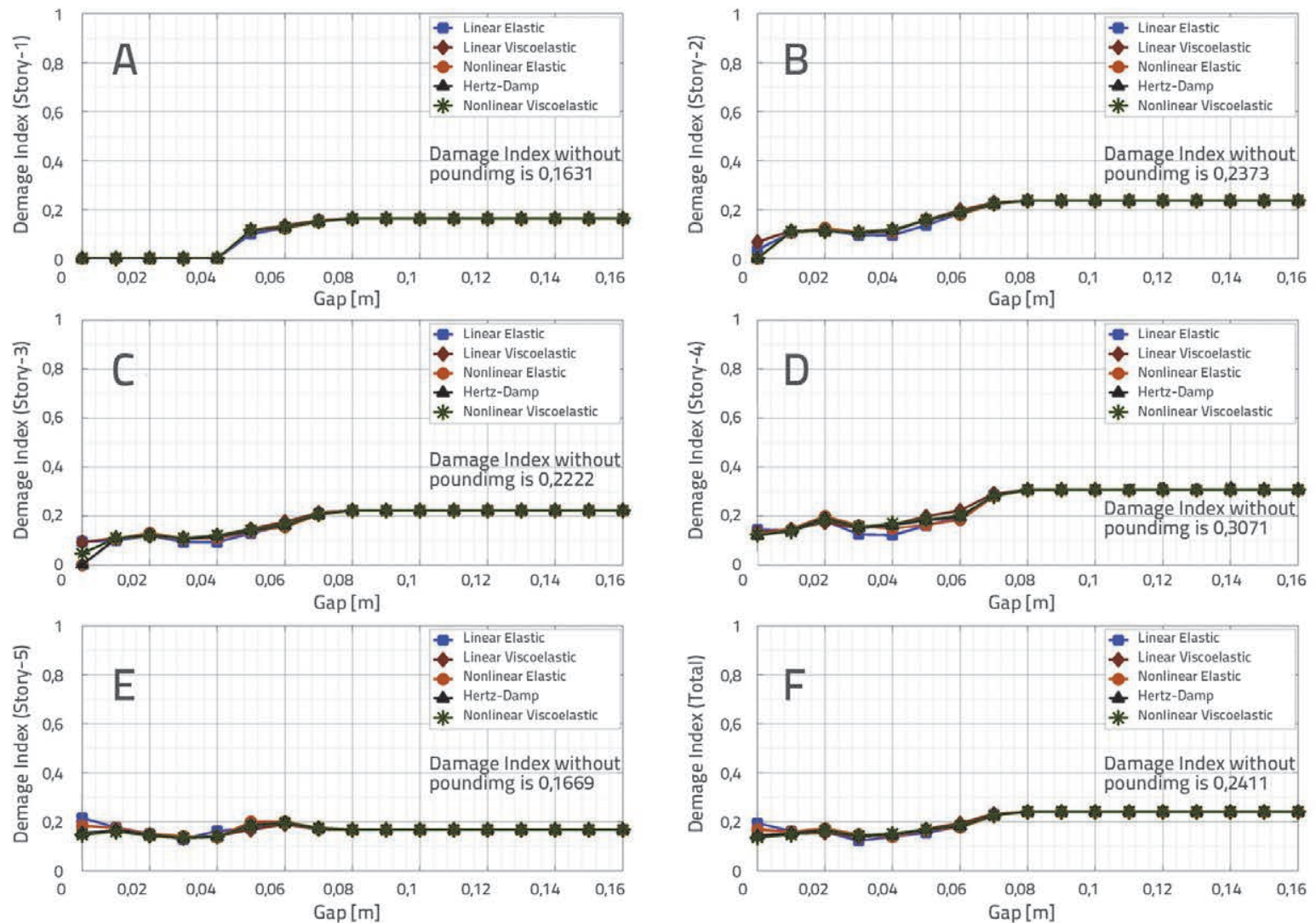

Figure 4. Park-Ang damage index in different separations for Superstitn Hills, left-to-right, A-first, B-second, C-third, D-forth, E-fifth storey and F-total frame
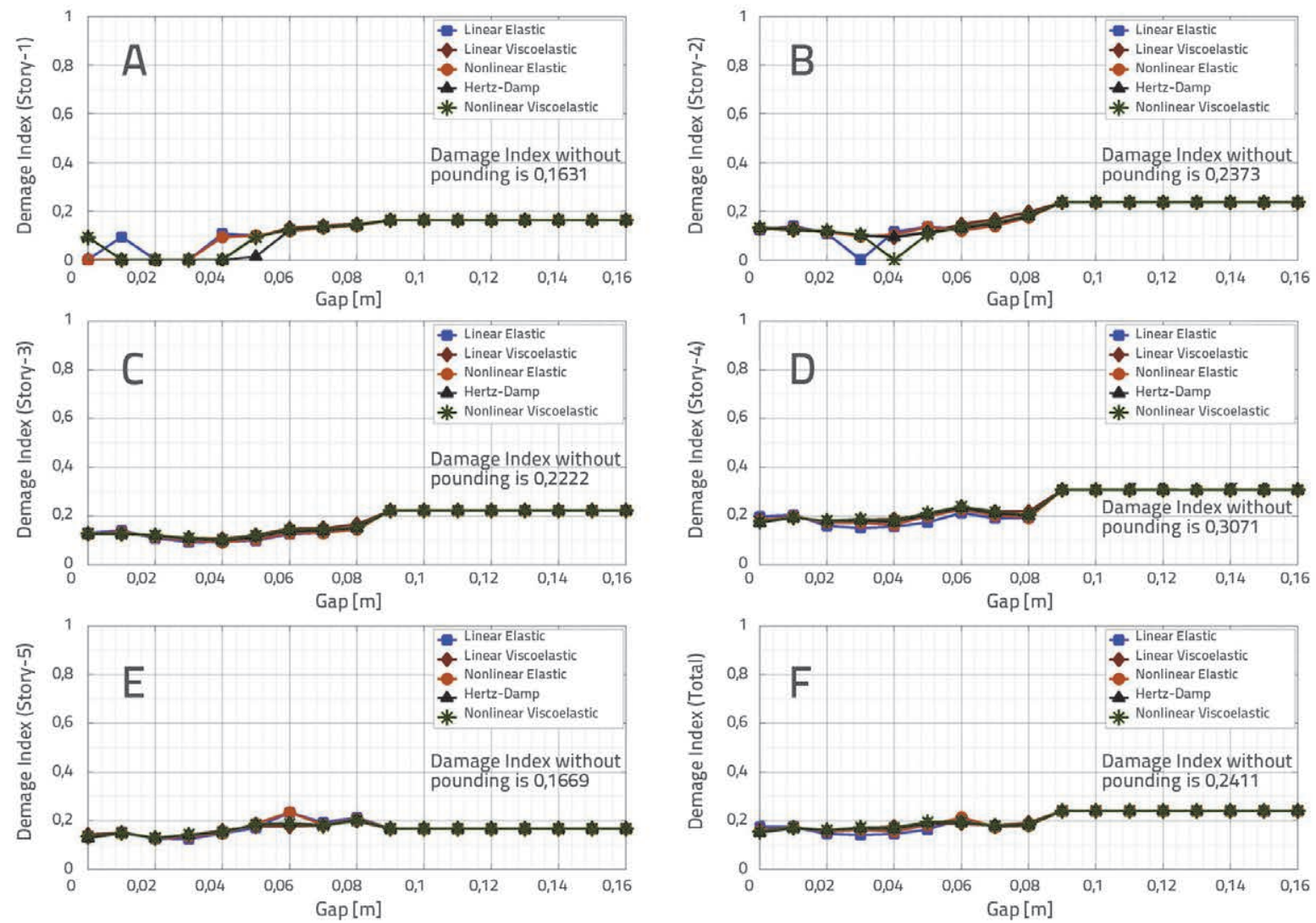

Figure 5. Park-Ang damage index in different separations for Superstitn Hills, right-to-left, A-first, B-second, C-third, D-forth, E-fifth storey and F-total frame 

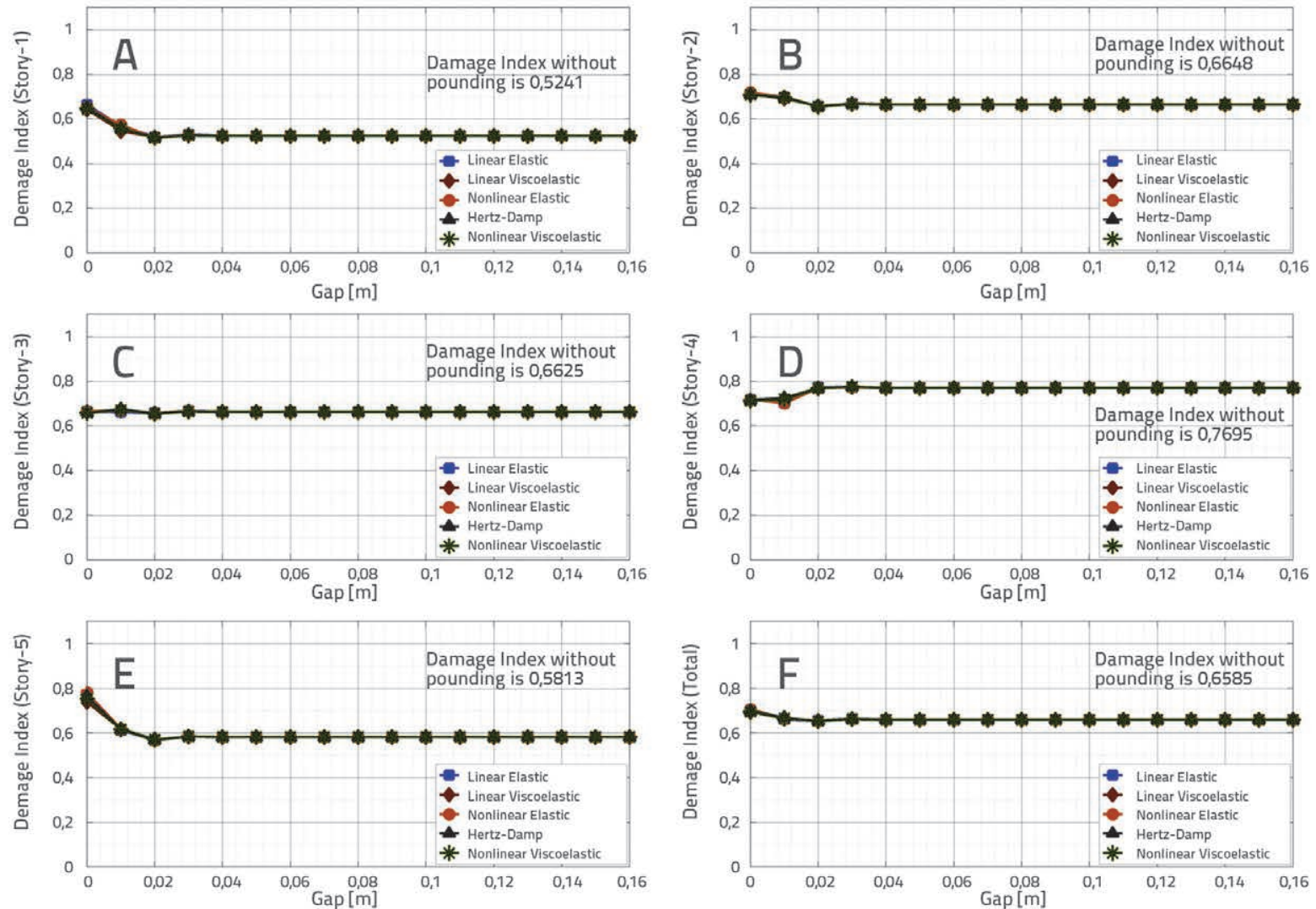

Figure 6. Park-Ang damage index in different separations for Northridge, left-to-right, A-first, B-second, C-third, D-forth, E-fifth storey and F-total frame
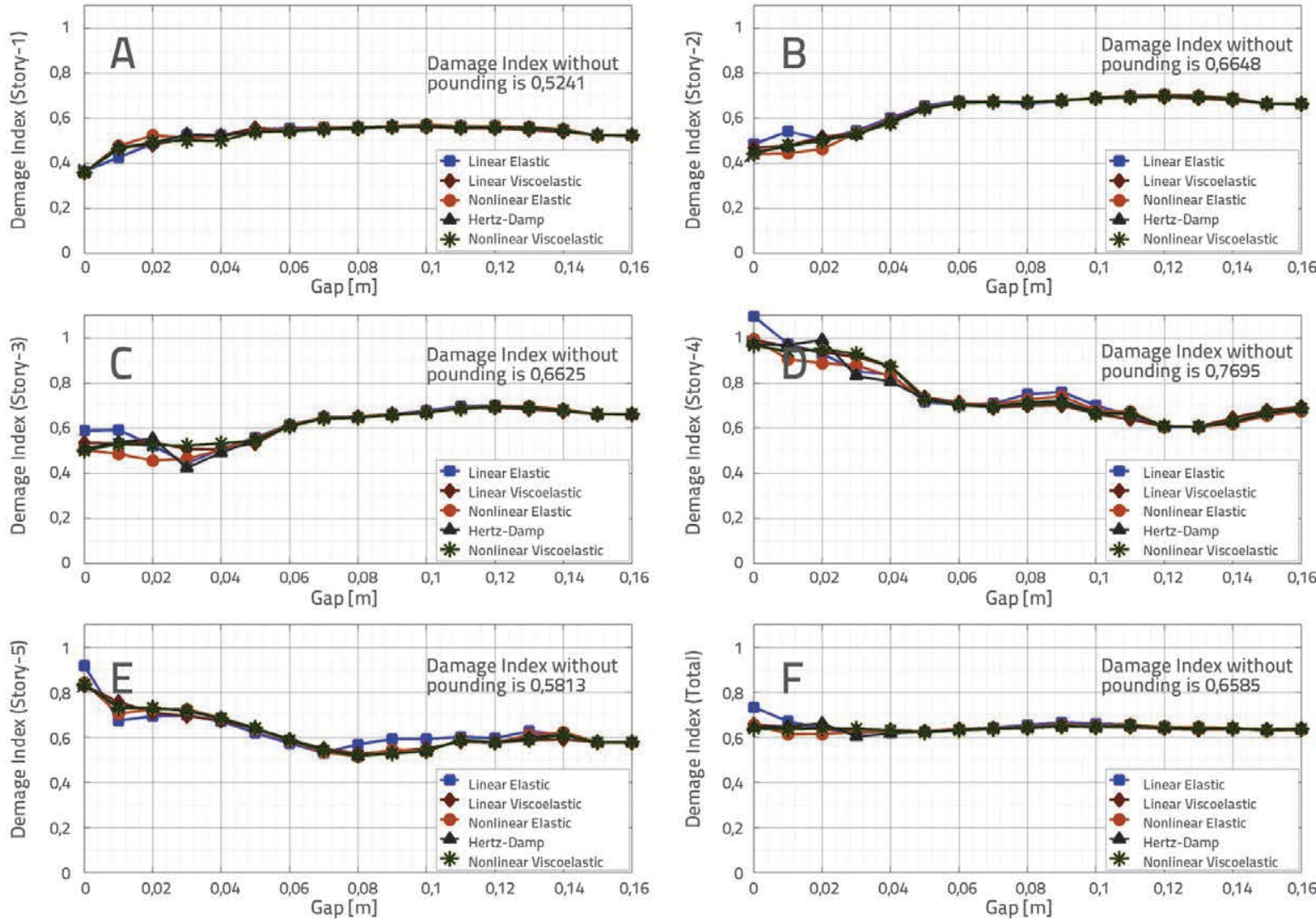

Figure 7. Park-Ang damage index in different separations for Northridge, right-to-left, A-first, B-second, C-third, D-forth, E-fifth storey and F-total frame 

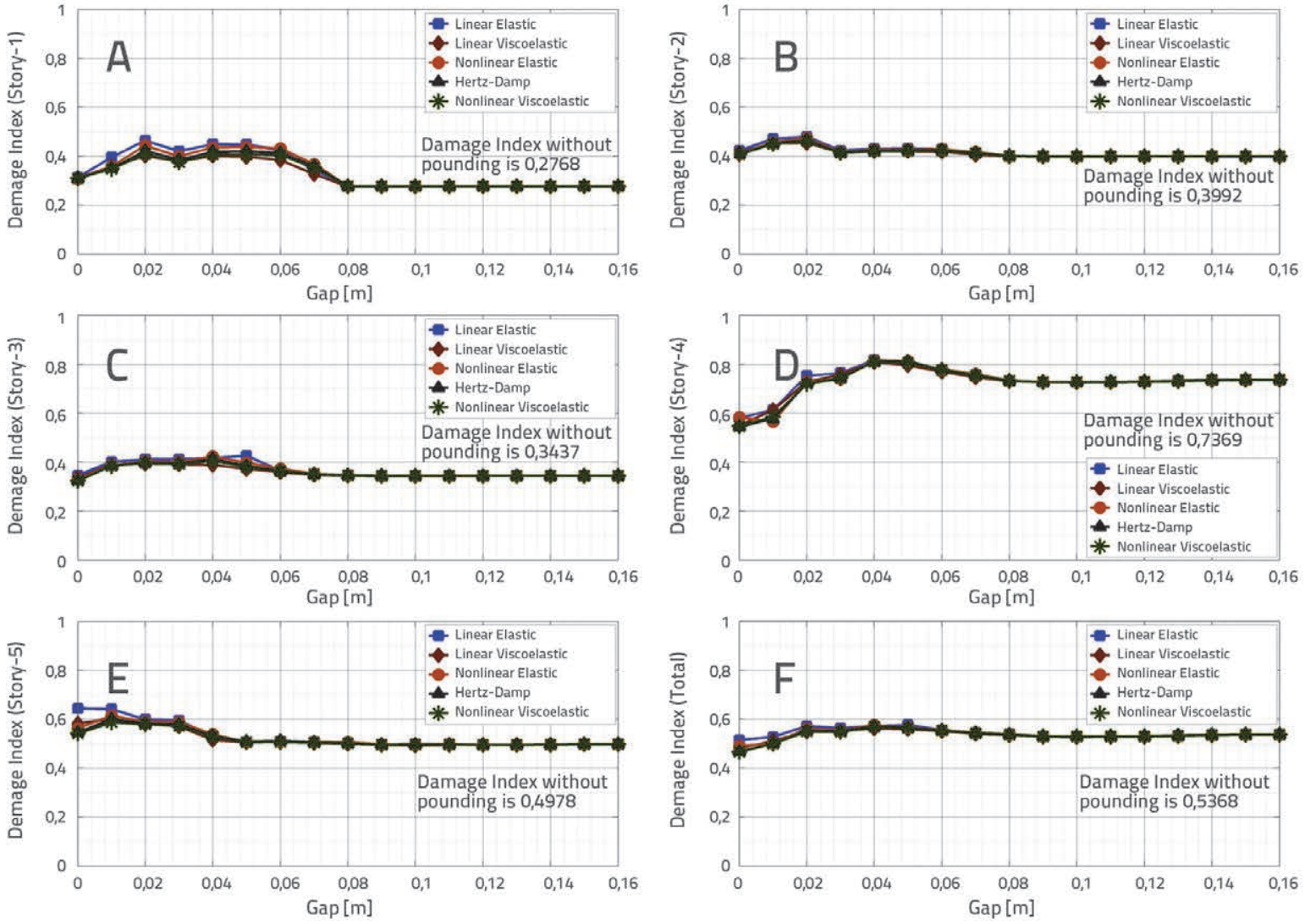

Figure 8. Park-Ang damage index in different separations for Duzce, left-to-right, A-first, B-second, C-third, D-forth, E-fifth storey and F-total frame
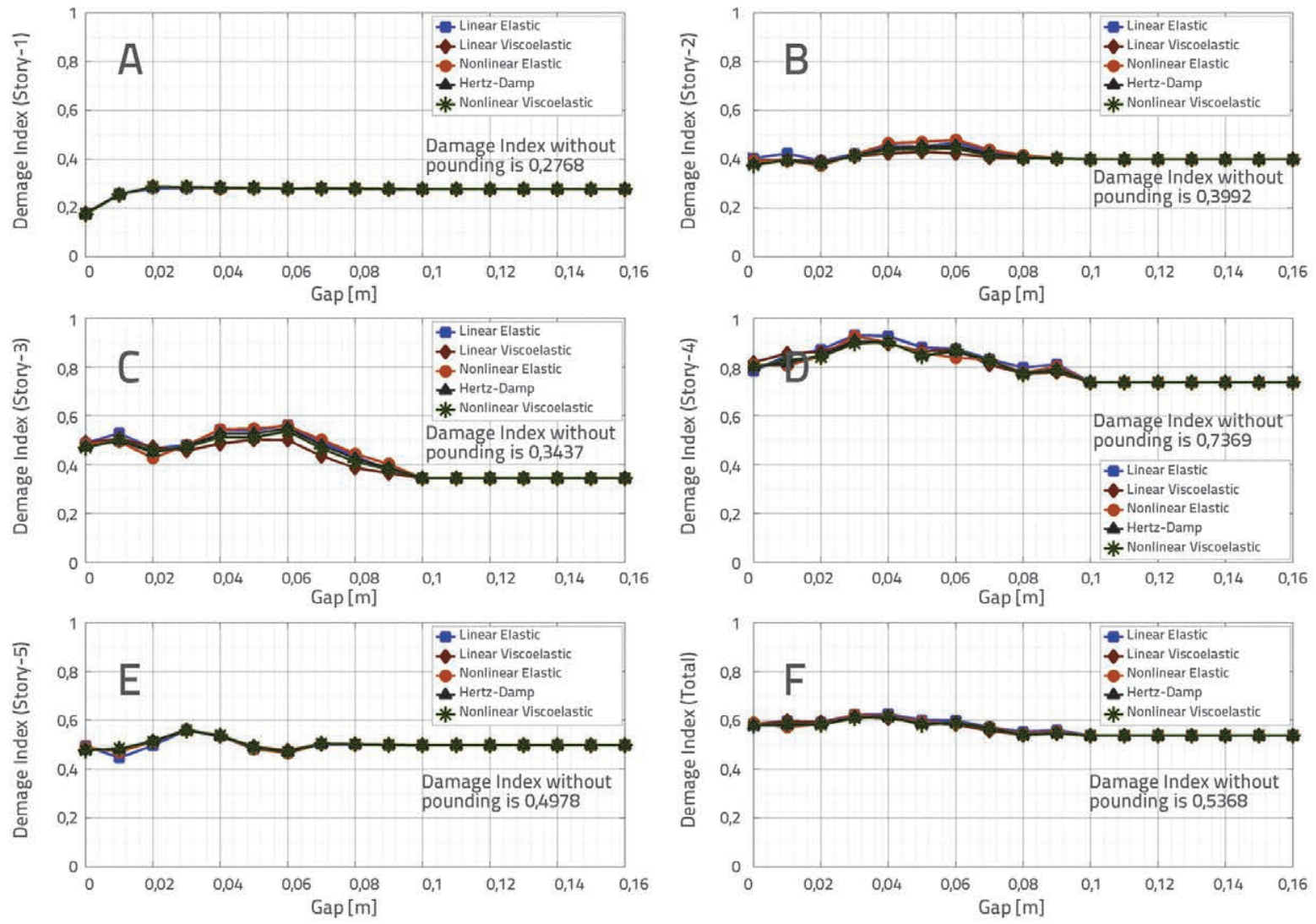

Figure 9. Park-Ang damage index in different separations for Duzce, right-to-left, A-first, B-second, C-third, D-forth, E-fifth storey and F-total frame 
Table 6. Maximum absolute differences (\%) of damage index (DI) occurring in gap $=0.16 \mathrm{~m}$ without pounding for hertzdamp model

\begin{tabular}{|c|c|c|c|c|c|c|c|}
\hline Ground motion & Direction & $\begin{array}{c}\text { Damage Index (DI) } \\
\text { at gap = 0.16 } \mathbf{~ m} \\
\text { for 3-bay frame }\end{array}$ & $\begin{array}{c}\text { DI for 3-bay } \\
\text { frame Without } \\
\text { pounding }\end{array}$ & $\begin{array}{c}\text { Difference } \\
{[\%]}\end{array}$ & $\begin{array}{c}\text { Damage Index (DI) } \\
\text { at gap = 0.16 } \mathrm{m} \\
\text { for 5-bay frame }\end{array}$ & $\begin{array}{c}\text { DI for 5-bay } \\
\text { frame Without } \\
\text { pounding }\end{array}$ & $\begin{array}{c}\text { Difference } \\
{[\%]}\end{array}$ \\
\hline Northridge & $\mathrm{R}-\mathrm{L}$ & 0,6363 & 0,6585 & 3,37 & 0,9296 & 0,9263 & 0,36 \\
\hline \multirow{2}{*}{ Chi-Chi (TCU074) } & $\mathrm{L}-\mathrm{R}$ & 1,0555 & 1,0429 & 1,21 & 1,0200 & 1,0314 & 1,11 \\
\cline { 2 - 8 } & $\mathrm{R}-\mathrm{L}$ & 1,0331 & 1,0429 & 0,94 & 1,0133 & 1,0314 & 1,75 \\
\hline Cape Mendocino & $\mathrm{R}-\mathrm{L}$ & 0,4508 & 0,4508 & 0,00 & 0,7157 & 0,7157 & 0,00 \\
\hline \multirow{2}{*}{ Chi-Chi (TCU079) } & $\mathrm{L}-\mathrm{R}$ & 0,8164 & 0,8164 & 0,00 & 1,0194 & 1,0198 & 0,04 \\
\cline { 2 - 8 } & $\mathrm{R}-\mathrm{L}$ & 0,8450 & 0,8164 & 3,50 & 1,0188 & 1,0198 & 0,10 \\
\hline
\end{tabular}

According to Tables 3 or 4 , in some ground motions the pounding forces are zero in the gaps greater than 1 percent of the frame height $(0.16 \mathrm{~m})$. Damage indices of these cases for the gap equalling $0.16 \mathrm{~m}$, and for the hertzdamp impact model, are presented in Table 6 . Table 6 shows that separation equals $1 \%$ of the frame height and that it can strongly affect pounding forces. However, according to Eq. (20), the UBC separation that equals: $0.331 \mathrm{~m}$, even for PGAs greater than $0.7 \mathrm{~g}$, is conservative..

\section{Conclusions}

The effects of different impact elements were analysed in this study. Therefore, these elements were programmed and added to the OpenSees library. Then, nonlinear dynamic analyses were conducted under eight ground motions to study pounding of two adjacent 5-storey frames in different gaps from 0.0 to 0.16 , with $0.01 \mathrm{~m}$ increment. The Park-Ang damage index was calculated in this study. Right and left frames had different masses so as to enable proper study of heavy structural pounding.

The results showed that:
- Stiffness should be assumed to specify characteristics of linear and nonlinear viscoelastic elements; but, nonlinear elastic and hertzdamp elements have fewer uncertainties. Therefore, the hertzdamp impact element can be a proper case for the pounding model which takes into account energy dissipation during impact.

- The Park-Ang damage index is affected by the pounding element selection. In general terms, pounding models with linear and nonlinear elastic elements induce maximum Park-Ang damage indices. The use of elastic impact elements is almost conservative. Stiffness which equals 20 times of storey building stiffness can be a proper value for modelling the linear elastic impact element.

- Pounding can increase or decrease damage to different storeys or to the total frame in different separations. Also, it can change damage to different storeys. Therefore, it is recommended to increase the separation between two adjacent buildings until effects of pounding become negligible.

- Separation equalling to $1 \%$ of the building height can strongly decrease the effect of pounding on damage index. The UBC regulation for determining gap of adjacent buildings is conservative.

\section{REFERNCES}

[1] Rosenblueth, E., Meli, R.: The 1985 Earthquake: Causes and Effects in Mexico City, Concrete International, 8, pp. 23-34, 1986.

[2] Kasai, K., Maison, B.F.: Observation of Structural Pounding Damage from 1989 Loma Prieta Earthquake, Proceeding Of 6th Canadian Conference of Earthquake Engineering, Toronto, Canada, pp. 735-742, 1991

[3] Anagnostopoulos, S.A.: Earthquake Induced Pounding: State Of The Art, Proceedings of the 10th European Conference on Earthquake Engineering, Balkema, Rotterdam, 2, pp. 897-905, 1995.

[4] Anagnostopoulos, S.A.: Building Pounding Re-Examined: How Serious A Problem Is It?, Proceedings of the 11th World Conference on Earthquake Engineering, Acapulco, Mexico, Paper No: 2108, 1996.
[5] Goldsmith, W.: Impact: The Theory and Physical Behaviour of Colliding Solids, Dover Pub, Inc., Edward Arnold, London, England, 1960.

[6] Stoykovich, M.: Nonlinear Effects in Dynamic Analysis and Design of Nuclear Power Plant Components: Research Status and Needs, Nuclear Engineering and Design, 50, pp. 93-114, 1978.

[7] Maison, B.F., Kasai, K.: Analysis for Type of Structural Pounding, Journal of Structural Engineering, 116, pp. 957 - 975, 1990.

[8] Maison, B.F., Kasai, K.: Dynamics of Pounding When Two Buildings Collide, Earthquake Engineering and Structural Dynamics, 21, pp. $771-786,1992$. 
[9] Karayannis, C., Favvata, M.: Earthquake-Induced Interaction between Two Adjacent Reinforced Concrete Structures with Non-Equal Heights, Earthquake Engineering and Structural Dynamics, 34, pp. 1-20, 2005

[10] Shatoff, H.D., Thompson, R.W., Lee, T.H.: Nonlinear Dynamic Analysis of Prismatic Elements for High-Temperature GasCooled Reactor Cores, Nuclear Engineering and Design, 59, pp. 185-195, 1980.

[11] Anagnostopoulos, A.: Pounding Of Buildings in Series during Earthquakes, Earthquake Engineering and Structural Dynamics, 16, pp. 443-456, 1988.

[12] Anagnostopoulos, A., Karamaneas, C.: Use of Collision Shear Walls to Minimize Seismic Separation and to Protect Adjacent Buildings from Collapse due to Earthquake-Induced Pounding, Earthquake Engineering and Structural Dynamics, 37, pp. 1371$1388,2008$.

[13] Lankarani, H.M., Nikravesh, P.E.: A Contact Force Model With Hysteresis Damping for Impact Analysis of Multibody Systems, Journal of Mechanical Design ASME, 112, pp. 369-376, 1990.

[14] Muthukumar, M., Desroches, R.: Evaluation of Impact Models for Seismic Pounding, 13th World Conference on Earthquake Engineering, Vancouver, Canada, Paper No: 235, 2004.

[15] Muthukumar, M., Desroches, R.: A Hertz Contact Model with Nonlinear Damping for Pounding Simulation, Earthquake Engineering and Structural Dynamics, 35, pp. 811-826, 2006.

[16] Jankowski, R.: Non-Linear Viscoelastic Modelling of EarthquakeInduced Structural Pounding, Earthquake Engineering and Structural Dynamics, 34, pp. 595-611, 2005.

[17] Jankowski, R.: Earthquake-Induced Pounding Between Equal Height Building with Substantially Different Dynamic Properties, Engineering Structure, 30, pp. 2818-2829, 2008.

[18] Mahmoud, S., Chen, X., Jankowski, R.: Structural Pounding Model with Hertz Spring and Nonlinear Damper, Applied Sciences, 8 , pp. 1850-1858, 2008.

[19] Vaseghi-Amiri, J., Jalali, S.G.: Study of Different Contact Elements in Poundings of Steel Buildings, Journal of Modelling in Engineering, 9, pp. 1-19, 2011.

[20] Veletsos, A.S., Newmark, N.M.: Effect Of Inelastic Behaviour on the Response of Simple Systems to Earthquake Motions, Proceedings of 2th World Conference on Earthquake Engineering, Tokyo, 2, pp. 895-912 1960.
[21] Lybas, J., Sozen, M.A.: Effect of Beam Strength Ratio on Dynamic Behaviour of Reinforced Concrete Coupled Walls, Report SRS No. 444, University of Illinois, Urbana Champaign, USA, 1977.

[22] Park, Y.J., Ang, A.H.S.: Mechanistic Seismic Damage Model for Reinforced Concrete, Journal of Structural Engineering, 111, pp. 722-739, 1985.

[23] Roufaiel, M.S.L., Meyer, C.: Analytical modelling of hysteretic behaviour of R/C frames, Journal of Structural Division, 113, pp. 429-444, 1987.

[24] McCabe, S.L., Hall, W.J.: Assessment of Seismic Structural Damage, Journal of Structural Engineering, 115, pp. 2166-2183, 1989.

[25] Fajfar, P.: Equivalent ductility factors, taking into account lowcycle fatigue, Earthquake Engineering and Structural Dynamics, 21, pp. 837-848, 1992.

[26] Jankowski, R.: Experimental Study on Earthquake-Induced Pounding between Structural Elements Made of Different Building Materials, Earthquake Engineering and Structural Dynamics, Short Communication, DOI: 10.1002/Eqe.941, 2009.

[27] OpenSees Manual, http://opensees.berkeley.edu/, Web page.

[28] FEMA, Prestandard and Commentary for the Seismic Rehabilitation of Buildings, FEMA 356, Washington, D.C., USA, 2000.

[29] Reinhorn, A.M., Kunnath, S.K., Valles-Mattox, R.: IDARC 2D Version 4.0: Users Manual, Department Of Civil Engineering, State University of New York At Buffalo, 1996.

[30] U.S. Geological Survey, http:// www.usgs.gov/, Web page.

[31] Standard 2800, Iranian Code of Practice for Seismic Resistant Design of Buildings, Building and Housing Research Center, Tehran, Iran, 2006.

[32] AISC-ASD, Specification for Structural Steel Buildings: Allowable Stress Design and Plastic Design, USA. 1989.

[33] ICBO, Uniform Building Code (UBC), International Conference of Building Officials, Whittier, California, USA, 1997.

[34] Peer Database, http://peer.berkeley.edu/peer_ground_ motion_database, Web page. 